\title{
Organizational Culture, Work Commitment and Compensation Effect on Job Satisfaction and Police Members Performance in Makassar Metropolitan City Police (POLRESTABES)
}

\author{
Saharuddin, Abdul Rahman Mus, Baharuddin Latief, and Budiandriani
}

\begin{abstract}
An important moment of the application of human resource management is to make every Police members in an organization able to carry out its vision, mission, main tasks and functions as well as the values adopted by an organization to progress and develop. The purpose of this study is to analyze the influence of organizational culture, commitment and compensation on job satisfaction and Police Members performance, to analyze the effect of job satisfaction on Police Members performance, and to analyze the influence of organizational culture, commitment and compensation through job satisfaction on Police Members performance.The study was conducted in Makassar metropolitan city police (Polrestabes) with a population of 2.160 people and the sample was determined by full sampling of 187 Police Members. Data from the questionnaire were analyzed using the Structural Equation Model using AMOS 18 assistance. The results of the study found that organizational culture and work commitment has a positive effect on Police Members satisfaction. Compensation and organizational culture has a negative effect on Police Members satisfaction. Directly, organizational commitment, compensation and job satisfaction has a positive effect on Police Members performance. Indirectly, organizational culture, organizational commitment and compensation through job satisfaction has a positive and significant effect on Police Members performance.
\end{abstract}

Index Terms-Organizational culture, satisfaction, performance, commitment, compensation

\section{INTRODUCTION}

Facing challenges and increasingly fierce work competition, the existence of human resources becomes important and needs to be managed and utilized in achieving organizational goals. An important moment of the application of human resource management is to make every existing police in an organization able to carry out the vision, mission, main tasks and functions as well as the values adopted by an organization to progress and develop.

Makassar Metropolitan city police (Polrestabes) is part of the Republic of Indonesia's National Police whose existence is as outlined in article 30 paragraph 4 of the 1945 Constitution of the Republic of Indonesia and the Republic

Published on April 16, 2020.

S. DN. , Indonesian Muslim University Makassar, Indonesia.

(e-mail: witabesmks74/@gmail.com)

A. R.M., Indonesian Muslim University Makassar, Indonesia.

(e-mail: abdul.rahman@umi.ac.id)

B. L. , Indonesian Muslim University Makassar, Indonesia.

(baharlatief@yahoo.com)

B. A., Indonesian Muslim University Makassar, Indonesia. of Indonesia's National Police Law number 2 of 2002 that the Police as a State tool that maintains security and community order has the duty to protect, protect, serve the community, and enforce the law. In implementing what is stated in article 30 paragraph 4 of the 1945 Constitution of the Republic of Indonesia, the Makassar metropolitan city police continues to work in synergy with all components of the community to create a condition of Makassar that is safe and conducive, so that the community can carry out activities without being followed the fear and worry arising from unsafe situations and conditions [1].

The reformation era that is rolling up to now, the Makassar metropolitan city police (Polrestabes) continues to strive to support and supervise so that reform can proceed in accordance with the expectations of the community. To realize this expectation Makassar metropolitan city police (Polrestabes) which is also part of government agencies has carried out reforms in the management of the organization both in terms of performance accountability and aspects of accountability in the use of state finances, where such provisions are as stated in Tap MPR RI No.XI / MPR / 1998 and Law No.28 of 1999 concerning the administration of a state that is clean, free from corruption, collusion and nepotism, requires a form of accountability related to the development and application of an appropriate, clear and periodic system [1,2].

The Security disturbances and crime are always evolving and dynamic along with the advancement of human civilization, science and technology but crime and security and public order disruptions (Kamtibmas) that occur in the Makassar metropolitan city police (Polrestabes) have so far both conventional and conventional transnational can still be relatively overcome and controlled.

The Internal of Makassar metropolitan city police (Polrestabes) there is the seriousness of the leadership in matters of order Indonesian Police Members (POLRI) especially the enforcement of all forms of irregularities / violations so that the impact has been felt by both police personnel and the community. This is indicated by the functioning of the disciplinary hearing institution, the trial code of ethics of the Police and when personnel involved in criminal acts will be processed through the general court and the more open public awareness to report the actions of police members who deviate [2].

The phenomenon regarding the performance of police officers in the metropolitan city police (Makassar Police) is not in accordance with the expected targets which resulted in only partially incoming case reports being resolved. This is indicated as a decrease in the level of satisfaction of members of the police in the Makassar metropolitan city 
police (Polrestabes) which resulted in decreased performance for members of the National Police. In the table below, data on the Makassar metropolitan city police (Polrestabes) Crime Report Data for 2017 are compared with 2018.

\section{METHODS}

Exploratory research to find a relatively new relationships, and explanatory research conducted by explaining the symptoms caused by an object of research. Judging from the aspect of the data is ex post facto, which means that after the event that is research that is systematic empirical search, where researchers can not control the independent variables because events have occurred or nature can't be manipulated. Judging from its purpose is a causal study that seeks to explain the causal relationship of the influence of organizational culture, commitment and compensation to the satisfaction and polices members performance in Makassar metropolitan city police (Polrestabes). Data collection techniques (instruments) was used observation, questionnaire, interview and documentation.

\section{A. Population and Sample}

The population in this study were all police members in the Makassar metropolitan city police (Polrestabes) which were taken purposively by determining two regions, namely the City having a total of 2,160 police personnel, bringing the total population to 2,160 police members.

TABLE I: POPULATION AND SAMPLES

\begin{tabular}{|c|c|c|c|}
\hline No. & Organizational Unit & $\begin{array}{l}\text { Number of } \\
\text { Personnel }\end{array}$ & $\begin{array}{l}\text { Number of } \\
\text { Samples }\end{array}$ \\
\hline 1. & $\begin{array}{l}\text { Makassar Metropolitan } \\
\text { city police }\end{array}$ & 1.032 & 89 \\
\hline 2. & Mariso Sectoral Police & 78 & 7 \\
\hline 3. & Mamajang Sectoral Police & 78 & 7 \\
\hline 4. & Bontoala Sectoral Police & 86 & 7 \\
\hline 5. & $\begin{array}{l}\text { Ujung Pandang Sectoral } \\
\text { Police }\end{array}$ & 81 & 7 \\
\hline 6. & Makassar Sectoral Police & 79 & 7 \\
\hline 7. & Tallo Sectoral Police & 88 & 8 \\
\hline 8. & $\begin{array}{l}\text { Panakukang Sectoral } \\
\text { Police }\end{array}$ & 108 & 9 \\
\hline 9. & $\begin{array}{l}\text { Biringkanaya Sectoral } \\
\text { Police }\end{array}$ & 115 & 10 \\
\hline 10. & Tamalate Sectoral Police & 119 & 10 \\
\hline 11. & Rappocini Sectoral Police & 120 & 10 \\
\hline 12. & $\begin{array}{l}\text { Sectoral Police of } \\
\text { Tamalanrea }\end{array}$ & 92 & 8 \\
\hline 13. & Manggala Sectoral Police & 84 & 7 \\
\hline \multicolumn{2}{|r|}{ Total Population } & 2.160 & Total Samples $=187$ \\
\hline
\end{tabular}

\section{B. Data Analysis}

Data analysis we used in explaining the phenomena in this study are descriptive statistical analysis and Structural Equation Modeling (SEM) analysis.

\section{a) Descriptive Analysis}

Descriptive statistical analysis is used to analyze data by describing or describing data collected as it is without intending to make conclusions that are applicable to the public [3]. Descriptive statistical analysis is used to explain the characteristics of respondents including gender, last education, age, and years of service. In addition, descriptive statistical analysis is also used to explain respondents 'responses to research variables including the influence of organizational culture, work commitment and compensation to job satisfaction and police members' performance. Calculations in descriptive statistical analysis are performed with the help of a computer using the AMOS 18 assistance and SPSS version 20.0 packages.

b) Inferential Analysis

Inferential analysis used is Structural Equation Model (SEM) analysis is a statistical analysis technique that combines several aspects contained in path analysis and confirmatory factor analysis to estimate several equations simultaneously. Structural equation model is a second generation multivariate analysis technique that allows researchers to examine the relationship between variables are complex both recursive and non-recursive to obtain an overall picture of the whole models [4].

\section{RESUlts AND DiscuSSION}

The results of the research and discussion of this study focus on the observed problems to be analyzed according to the results of data processing using statistics after the data are tabulated and validated in normality and reliability. Furthermore, frequency is performed to analyze the characteristics of respondents on each variable according to the indicators, then analysis is done an SEM (Structural Equation Model) to see the construct of variables in accordance with the eight criteria for goodness of fit to test hypotheses in seeing direct effects and indirect effect which is positive or negative and significant or insignificant.

TABLE II: RESPONSES ON ORGANIZATIONAL CULTURE

\begin{tabular}{c|c|c}
\hline Indicators & \multicolumn{2}{|c}{ Mean } \\
\hline Integrity & 4.52 & \\
\hline Identity & 4.43 & \multirow{2}{*}{4} \\
\cline { 1 - 2 } Responsibilities & 4.47 & \\
\hline Discipline & 4.45 & \\
\hline Result orientation & 4.46 &
\end{tabular}

Based on the table, it can be seen that organizational culture indicators in the form of high integrity in the workplace are dominant in terms of the mean and mode shown, which means that the application of organizational culture of each member of the National Police is very supportive in the achievement of optimization by basic tasks and functions

TABLE III: RESPONSES ON ORGANIZATIONAL COMMITMENT

\begin{tabular}{c|c|c}
\hline Indicators & \multicolumn{2}{|c}{ Mean } \\
\cline { 1 - 2 } Affective commitment & 4.31 & \\
\cline { 1 - 2 } Normative commitment & 4.39 & \multirow{2}{*}{4.38} \\
\cline { 1 - 2 } Continuance commitment & 4.43 & \\
\hline Perspective commitment & 4.40 & \\
\hline
\end{tabular}

Organizational commitment Indicator in the form of pledged sustain organizational success of the dominant views of the mean indicated, which means that each member of the national police is committed to furthering the 
organization he works

TABLE IV: RESPONSES ON COMPENSATION

\begin{tabular}{c|c|c}
\hline \multicolumn{2}{|c}{ Mean } \\
\hline Indicators & 4.41 \\
\hline Salary & 4.44 \\
\hline Incentives & 4.46 & \multirow{2}{*}{4.45} \\
\hline Allowance & 4.50 & \\
\hline Facility & & \\
\hline
\end{tabular}

Accordingly, visible indicators of compensation, the dominant facility seen from the mean values shown, which means the existence of the facility as the provision of nonfinancial remuneration that takes police to the ease and smoothness of work activities.

\begin{tabular}{c|c|c}
\multicolumn{2}{c}{ TABLE V: RESPONSES ON JOB SATISFACTION } \\
\hline Indicators & \multicolumn{2}{|c}{ Mean } \\
\hline Jobs Interesting & 4.45 \\
\hline Work challenges & 4.50 & \multirow{3}{*}{4} \\
\hline Achievement & 4.46 \\
\hline Award & 4.45 & \\
\hline Promotion & 4.40 \\
\hline
\end{tabular}

Job satisfaction indicators in the form of dominant achievement efforts can be seen from the indicated mean value, which means job satisfaction of members of the police is determined by work performance as fulfillment of job satisfaction which is a tribute to the success of police officers reaching the target.

TABLE VI: RESPONSES ON JOB PERFORMANCE

\begin{tabular}{c|c|c}
\hline Indicators & \multicolumn{2}{|c}{ Mean } \\
\hline Quantity & 4.39 \\
\hline Quality & 4.47 \\
\hline Time & 4.50 & \multirow{2}{*}{4.47} \\
\hline Cost & 4.51 & \\
\hline
\end{tabular}

Job performance indicator in the form of a dominant budget allocation is seen from the indicated mean, which means that members of the police force use budget allocations or funds effectively to facilitate work completion

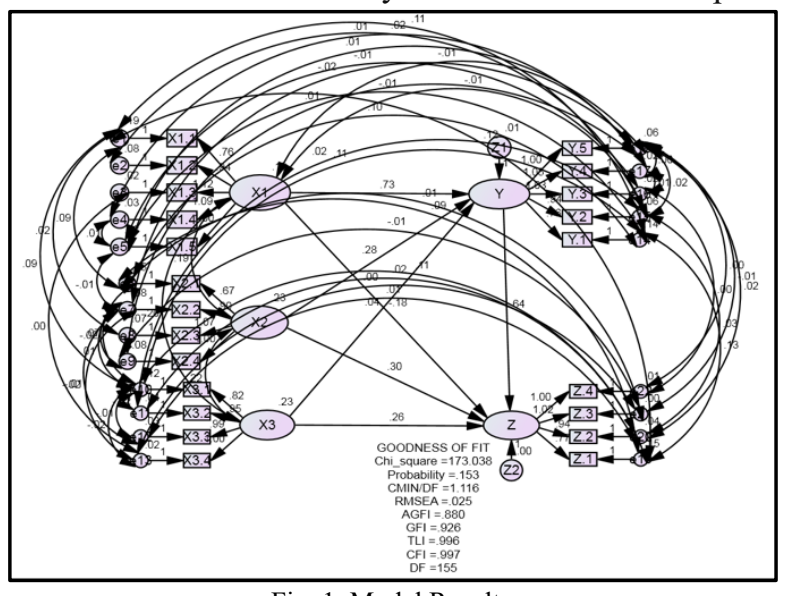

Fig. 1. Model Results

The model test results presented in Figure 1 above are evaluated based on the goodness of fit indices in Table 7 below, with the model criteria and their critical values having a data suitability presented.

TABLE VII: GOODNESS OF FIT INDICES

\begin{tabular}{c|c|c|c|c}
\hline $\begin{array}{c}\text { Goodness of } \\
\text { fit index }\end{array}$ & $\begin{array}{c}\text { Cut-off } \\
\text { Value }\end{array}$ & early & final & remarks \\
\hline Chi_Square & $\leq$ small & 1316.812 & 173.038 & Fit \\
\hline Probability & $\geq 0.05$ & 0.000 & 0.153 & Fit \\
\hline CMIN/DF & $\leq 2.00$ & 6.617 & 1.016 & Fit \\
\hline RMSEA & $\leq 0.08$ & 0.174 & 0.025 & Fit \\
\hline GFI & $\geq 0.90$ & 0.579 & 0.926 & Fit \\
\hline AGFI & $\geq 0.90$ & 0.465 & 0.880 & Fit \\
\hline TLI & $\geq 0.94$ & 0.809 & 0.996 & Fit \\
\hline CFI & $\geq 0.94$ & 0.835 & 0.997 & Fit \\
\hline Df & & 199 & 155 & \\
\hline
\end{tabular}

The results of the model evaluation for the initial stage show that of the eight criteria, goodness of fit indices there are only two that meet the criteria, cut-off value namely CMIN / DF and RMSEA, so that the model modification still needs to be done in accordance with the instructions of the modification indices, as previously explained. After modifying the model, the final stage shows that there are seven criteria for goodness of fit indices that meet the cut off value, so that the model can be said to be in accordance with the criteria for goodness of fit indices for analysis [5].

\section{A. Organizational Culture effect on Police Members Satisfaction}

The results of the research prove that organizational culture directly has a positive and significant effect on job satisfaction of police members. Organizational culture has a positive effect because the indicators of organizational culture in the form of integrity, identity, responsibility, discipline and overall orientation Police members actualize well in providing reinforcement on the application of organizational culture to carry out their main duties and functions [6], but the application of organizational culture has a significant effect on satisfaction work because members of the police force in carrying out their work activities are inseparable from the philosophical values that become a normative habit that binds every member of the police force to realize their satisfaction in terms of doing interesting work, happy with work challenges, able to show work performance, want to get appreciation and deserve to be promoted.

\section{B. Work Commitment effect on Police Members Satisfaction}

Based on the results of research in proving the hypothesis of the proposed problem, it is evident that work commitment directly has a positive and significant effect on job satisfaction. This gives an indication that all indicators of work commitments $[7,8]$ in the form of affective, normative, continuous and perspective commitments simultaneously strengthen positive work commitments and this also contributes significantly to increasing job satisfaction of police members in facing work dynamics that are 
increasingly full of challenges weight.

\section{Compensation effect on Police Members satisfaction}

After conducting research, the results were found that showed that compensation directly had a positive and insignificant effect on job satisfaction of members of the police force. Members of the police in carrying out their main duties and functions always expect to get compensation in accordance with what is done as a reward that is appropriate and appropriate to be received, so that job satisfaction is fulfilled by police members in carrying out their work [9]. The reasons for compensation have a positive and not significant effect on job satisfaction of police members, it is known that the main objective of every police officer in working is to get compensation and always try to increase their compensation by continuing to pay attention and improve the work they are engaged in so that the organization pays a salary every month in accordance with the main tasks and functions, wanting to get incentives from each additional work activity done.

\section{Organizational Culture effect on Police Members Performance}

Organizational culture has a negative and insignificant effect because the indicators of organizational culture in the form of integrity, identity, responsibility, discipline and results orientation [11] are not yet entirely Members of the National Police can actualize the application of organizational culture, so that the application of this organizational culture has no significant effect on performance because members of the police in carrying out their work activities do not practice the philosophical values which become a normative habit that is binding for each police member to improve their performance according to the achievement of work results in terms of quantity, quality, time efficiency and cost effectiveness.

\section{E. Work Commitment effect on Police Members Performance}

Work commitment has a positive and significant effect on the performance of Police Members, because the commitment they have is oriented towards the achievement of work results [10], it can be seen that the work commitments held by the Police Members encourage the Police Members to achieve work results in quantity based on the number of jobs, able completing the large amount of work assigned to them, their commitments are oriented to improving the quality of work in accordance with the dedication of their work, the work commitments of police officers lead to the completion of work on time, and the commitment of members of the police to pay attention or consider the use and use of costs to facilitate the achievement of work. This commitment which is oriented towards creating work results causes a significant work commitment to the performance of members of the police force. More clearly explained each indicator of work commitment variables that have a positive and significant effect on performance.

\section{F. Compensation effect on Police Members Performance}

Compensation police members have a positive and significant effect on the performance of police members, it is known that police members in carrying out their work always expect to receive compensation and always strive to increase their compensation by continuing to pay attention and improve the achievement of the results of their work in order to have the eligibility to receive salary every months in accordance with the results of work achieved, deserve incentives from each additional work, get benefits in the form of insurance and health insurance [12, 13, 14] for members of the police and want to get work facilities provided by the organization to facilitate their work. This desire for compensation is a remuneration expected by police members to be obtained, thus making police members continue to work hard to obtain optimal work results to improve the performance of police members in accordance with the achievement of work results in quantity, carry out quality work, do work in a quality manner efficient on time and utilize the budget effectively.

\section{G. Job Satisfaction effect on Police Members} Performance

Interesting work indicators are an element of job satisfaction assessment possessed by police members in carrying out their main duties and functions. Members of the police in developing the mandate of the work provided are always happy to face interesting routine work [15, 16,17], Members of the police do not feel bored with their routine work. This has caused interesting work to have a positive and significant effect on the performance of police officers. That is, members of the police feel satisfied in doing interesting work faced every day to improve their performance

H. Organizational Culture as a mediating role of Job Satisfaction effect on Police Members Performance

Organizational culture has a negative and insignificant effect due to indicators of organizational culture in the form of integrity, identity, responsibility, discipline and results orientation that are applied through job satisfaction has not been actualized properly $[19,20]$, so the application of this organizational culture has a negative effect insignificant on performance because the Police Members in carrying out their work activities do not practice the philosophical values which become a normative habit that is binding for every Police Member to improve their performance according to the achievement of work results in terms of quantity, quality, time efficiency and cost effectiveness. That is the reason that the organizational culture applied so far has a negative and not significant effect on the performance of police officers.

I. Work Commitment as a mediating role of Job Satisfaction effect on Police Members Performance

Work commitment in an organization is always considered and has a large contribution through job satisfaction towards improving organizational performance. Work commitment is defined as an effort to increase the compliance of a police officer to carry out the main duties and functions in an organization. Considering the existence of work commitments owned by police personnel is very 
urgent to consider through job satisfaction with the performance of police officers.

\section{J. Compensation as a mediating role of Job Satisfaction effect on Police Members Performance}

The effect of compensation as a mediating role of job satisfaction on performance obtained research results which indicate that indirectly compensation through job satisfaction has a positive and significant effect on the performance of Police Members. Means that the Police members are a carrying out their routine work always expect to get compensation as compensation according to expected job satisfaction. Providing compensation through job satisfaction makes police members try to always improve their performance. The reason for giving compensation through job satisfaction has a positive and significant effect on the performance of police members, because every police member who works has the aim to increase income from the compensation received. Fulfillment of appropriate and appropriate compensation makes police Members feel fulfilled their job satisfaction. The provision of compensation through the fulfillment of job satisfaction causes members of the police to always strive to carry out their work in order to produce optimal work, which affects the performance improvement of police members. Or in other words the effect of compensation through job satisfaction has a great significance on improving the performance of police officers.

\section{CONCLUSION}

Directly effect, organizational culture has a positive and significant effect on job satisfaction of the police members in Makassar Metropolitan city police (Polrestabes). Organizational culture is well actualized, but the existence of organizational culture plays an important role in increasing job satisfaction. Members of the police in Makassar Metropolitan city police (Polrestabes). Organizational commitment has a positive and significant effect on job satisfaction of police members in Makassar Metropolitan city police (Polrestabes). Each member of the police force has committed in accordance with the level of job satisfaction in carrying out duties and functions. Compensation has a positive and insignificant effect on job satisfaction of police member in Makassar Metropolitan city police (Polrestabes). Provision of compensation is appropriate for members of the police to feel in return and members of the police are satisfied with the compensation received.

Organizational culture has a negative and not significant effect on police member's performance in Makassar Metropolitan city police (Polrestabes). Organizational culture that has not been actualized properly has caused the police members performance in Makassar Metropolitan city police (Polrestabes) to decline. Organizational commitment has a positive and significant impact on police member's performance in Makassar Metropolitan city police (Polrestabes). Organizational commitment has been actualized well by police members in an effort to improve their performance. Compensation has a positive and significant effect on police member's performance in
Makassar Metropolitan city police (Polrestabes). Compensation provided has important meaning for members of the police force in improving its performance. Job satisfaction has a positive and significant effect on police member's performance in Makassar Metropolitan city police (Polrestabes). Job satisfaction felt by members of the police is in accordance with the achievement of their performance.

Indirectly effect of organizational culture through job satisfaction has a positive and significant effect on police member's performance in Makassar Metropolitan city police (Polrestabes). Organizational culture through job satisfaction that has been carried out so far has been actualized well, so that the police member's performance in Makassar Metropolitan city police (Polrestabes) has decreased. Organizational commitment through job satisfaction has a positive and significant effect on police member's performance in Makassar Metropolitan city police (Polrestabes). Commitment through job satisfaction has been actualized well which causes the police member's performance in Makassar Metropolitan city police (Polrestabes) to increase. Compensation through job satisfaction has a positive and significant effect on police member's performance in Makassar Metropolitan city police (Polrestabes). Compensation through job satisfaction has been implemented in accordance with the granting of compensation to improve the police member's performance in Makassar Metropolitan city police (Polrestabes).

\section{REFERENCES}

[1] Republic of Indonesia, (2018). Regulation Number 2 Year 2018 Regarding Performance Appraisal of Members of the Republic of Indonesia National Police With a Performance Management System.

[2] Republic of Indonesia. (2011). Regulation of the Chief of Police (Perkap) Number 6 Year 2011 May 31, 2011 concerning Procedures for Providing Performance Allowances for Civil Servants in the National Police.

[3] Masri Singarimbun, \& Efendi, S. (2005). Survey Research Methods, LPJES Library.

[4] Ghozali, I. (2005). Multivariate analysis application with SPSS. Semarang: UNDIP Publisher Agency

[5] Hair, J. F., Black, W. C., Babin, B. J., Anderson, R. E., \& Tatham, R. L. (1998). Multivariate data analysis (Vol. 5, No. 3, pp. 207-219). Upper Saddle River, NJ: Prentice hall.

[6] Muhtasom, A., Mus, H. A. R., Bijang, J., \& Latief, B. (2017). Influence of Servant Leadership, Organizational Citizenship Bahaviour on Organizational Culture and Employee Performance at Star Hotel in Makassar. Star, 486(206), 410.

[7] Sjahruddin, H., \& Sudiro, A. A. (2013). Organizational justice, organizational commitment and trust in manager as predictor of organizational citizenship behavior. Interdiciplinary J. of contemporary Res. Bus.(IJCRB), 4(12), 133-141.

[8] Dong, M., Mahfudnurnajamuddin, M., Semmaila, B., \& Latief, B. (2019). Contributions Of Human Resources Development, Leadership Style, Organizational Commitment, And Work Motivation On Good Governance And Police Officer Performance (Study Of Police Officer In South Sulawesi Regional Police). European Journal of Business and Management Research, 4(6).

[9] Mursid, A., Mahfudnurnajamuddin, M., \& Serang, S. (2019). The Effect of Organizational Climate, Compensation and Work Environment on Employee Job Satisfaction on Land in Bantaeng Regency. PARADOX: Journal of Economics, 2(3), 73-80.

[10] Sjahruddin, H., \& Normijati, A. A. S. (2013). Personality effect on organizational citizenship behavior (OCB): trust in manager and organizational commitment mediator of organizational justice in Makassar City Hospitals (Indonesia). European Journal of Business and Management, 5(9), 95-104.

[11] Muhtasom, A., Mus, H. A. R., Bijang, J., \& Latief, B. (2017). Influence of Servant Leadership, Organizational Citizenship Bahaviour on Organizational Culture and Employee Performance at Star Hotel in Makassar. Star, 486(206), 410. 
[12] Tone, K., Gani, M. U., Nujum, S., \& Latif, B. (2015). The impact of the antecedent variables on lecturer'performance as mediated by work motivation. International Journal of Humanities and Social Science Invention, 4(10), 54-62.

[13] Toban, C., \& Sjahruddin, H. (2016). The antecedent and consequence of Organizational Commitment and Job Satisfaction. Journal of Business and Management Sciences, 4(2), 26-33.

[14] Reynaldi, R., Ridjal, S., \& Sjahruddin, H. (2019). The Role Of Organizational Citizenship Behavior In Work Performance: An Investigation Based On Hotel Employee Survey. European Journal of Business and Management Research, 4(6).

[15] Nur, IG, \& Sjahruddin, H. (2019). The Effect of Transformational Leadership and Work Motivation on Employee Performance.

[16] Alfian Muukhtar, (2018) The Influence of Competence organsasional,culture and work stress on job statisfaction and performance of Syariah Bank in Makassar

[17] Ayesha Yasin, (2013). Effect of Compensation Factors on Employee Satisfaction - A Study of Doctor Dissatisfaction in Punjab. International Journal of Human Resource Studies ISSN 2162-3058 2013, Vol. 3, No. 1

[18] Fatwati Saleh, (2017) Affect of Transaction Leadership, Organization Culture, Commitment and Compensation toward Satisfaction and Performance by Employee on Farming Quarantine South Sulawesi Area

[19] Yanda Bara Kusuma, (2018). Effect of Compensation on Work Motivation, Job Satisfaction, and Employee Performance (Study of Permanent Employees of PT. Otsuka Indonesia)

[20] Wagiman \& Himawan (2018). The Effect of Organizational Culture, Organizational Commitment and Job Satisfaction on Employee Performance (Study at PT. Bank Rakyat Indonesia (Persero) Tbk. Semarang Regional Office) 